\title{
JUAN IGNACIO DE ARMAS Y LA DIALEGTOLOGÍA HISPANOAMERICANA
}

La filología hispánica fue sólo uno entre los variados intereses que, durante buena parte de la segunda mitad del siglo XIX, ocuparon la multifacética actividad del escritor, periodista y patriota cubano Juan Ignacio de Armas y Céspedes.

Aunque su contribución a la filología y a la dialectología hispanoamericana no tuvo la importancia de la de un Esteban Pichardo, o de un Antonio Bachiller en Cuba, y fuera de la isla, la de un Rufino José Cuervo o de un Andrés Bello, ella nos muestra a un acucioso y versado diletante poseedor de una aguda intuición. A pesar de que carecía de una formación filológica rigurosa, la actitud con que enfrentaba los fenómenos de la lengua no puede menos que calificarse de científica, en el sentido actual del término, actitud poco frecuente en su tiempo, y que lo acerca a los especialistas de épocas posteriores. En efecto, él se situaba como un observador que veía en la norma caribeña una entidad dotada de validez, una entidad que merecía tanto respeto como la norma peninsular o sus hermanas hispanoamericanas.

Poseemos escasos datos sobre el quehacer filológico de $\mathrm{De} \mathrm{Ar}-$ mas. La breve biografía que nos proporcionan Alonso y Fernán$\mathrm{dez}^{1}$ nos informa que sus intereses filológicos lo llevaron, entre otras actividades, a sostener una polémica sobre modalidades verbales con Enrique J. Varona, y que además escribió Las etimologías de la Academia (1886) y Orígenes del lenguaje criollo (1882, segunda edición). Este interés por la filología estaba íntimamente unido con el que sentía por la antropología, y ambos se supeditaban a uno quizá más profundo por la historia de su patria. Su interés y trabajos en estos campos le ganaron el honor de ser

${ }^{1}$ Gladys Alonso y Ángel Luis Fernández, Antología de lingüistica cubana, Editorial de Ciencias Sociales, La Habana, 1977, t. 1, p. 114. 
aceptado como miembro correspondiente de la Real Academia de la Historia de Madrid, y de la Sociedad Antropológica de Italia. Durante su relativamente corta vida dirigió y colaboró con diversos periódicos, tanto en Cuba como en Nueva York, a donde se trasladó en 1869, después del estallido de la guerra en su patria.

De sus obras de carácter filológico, nos interesa particularmente Orígenes del lenguaje criollo, porque en ella expuso las opiniones sobre el español de América que queremos analizar en esta ocasión.

Aunque ignoramos en qué fecha escribió los Origenes, suponemos que la primera edición debió aparecer hacia mediados de la década del setenta, poco tiempo después que las Apuntaciones críícas de Cuervo vieran la luz en Bogotá.

Esta obra sitúa a De Armas entre los primeros que proponían la existencia de diversas zonas dialectales en Hispanoamérica. El autor cubano dividía el Nuevo Mundo en cuatro, o tal vez cinco zonas: la primera comprendía el litoral del mar Caribe, es decir, las Antillas, Venezuela, Colombia que entonces incluía a Panamá, y "alguna parte de Centro América" (p. 5) ${ }^{2}$ que él no precisaba; la segunda comprendía México y el resto de la América Central, luego ubicaba otra, o quizá dos, en la costa del Pacífico de América del Sur, y una última en la región del Río de la Plata, donde ${ }^{6}$ Buenos Aires. . como más apartado del foco de pureza del idioma, va actualmente por delante en la natural formación de un idioma propio"' (p. 6).

Importa destacar que esta clasificación coincide en gran medida con la que casi medio siglo después propuso Pedro Henríquez Ureña y lo que es aún más interesante es el hecho de que los criterios adoptados para ambas clasificaciones fueron absolutamente opuestos. En efecto, mientras para las Antillas De Armas negaba la influencia indígena en la formación de ese dominio, y para los restantes parecía apenas reconocerla, atribuyendo la diferenciación principalmente a factores que operaban dentro del sistema de cada variedad, a la influencia indígena le cabía un papel exageradamente importante en la clasificación de Henríquez Ureña. Recordemos que el dominicano establecía cinco zonas que se definían respectivamente por la mezcla del español

${ }^{2}$ Me baso en la siguiente edición: Juan Ignacio de Armas y Céspedes, Orígenes del lenguaje criollo, $2^{a}$ ed., Imprenta de la Viuda de Soler, La Habana, 1882; en adelante indicaré el número de página entre paréntesis. 
con las lenguas nahuas en Nuevo México, México y la América Central; con el caribe y arauaco en las Antillas; con el quechua en la costa del Pacífico de Colombia, en Ecuador, Perú y norte de Chile; con el araucano en el centro y sur de Chile; y con el guaraní en Argentina y Paraguay.

Declarábamos más arriba que la actitud de De Armas hacia las variedades hispanoamericanas era una actitud sumamente moderna, esto no obstante el recién citado comentario sobre "el foco de pureza del idioma": él veía el cambio lingüístico como un proceso inevitable y a la vez necesario, porque "las leyes del transformismo no pueden alterarse en la ciencia filológica, como en ninguno de los otros ramos a que se extiende el estudio de las ciencias naturales" (p. 6). Esta evolución, al igual que en el resto de la naturaleza, importaba un perfeccionamiento, era la manera como la lengua se adaptaba a las variadas exigencias que le imponían los diversos medioambientes en constante cambio. Aunque aceptaba los criterios tradicionales de corrección, no por eso despreciaba las variedades latinoamericanas.

Para él, estas nuevas normas que veía en proceso de formación tenían tanta validez y debían ser objeto del mismo respeto que la norma peninsular. Nos atrevemos a decir, desde nuestra postura de cultores de la teoría de la lengua culta, que De Armas concebía estas variedades como entidades que rápidamente estaban alcanzando rango de normas cultas. En ellas, la función se-paradora, según la describe esta teoría, estaba en camino de triunfar sobre la función unificadora de la norma panhispánica, lo cual De Armas parecía ver como un proceso natural, inevitable e irreversible. Una vez que estas variedades hubieran alcanzado dicha meta, entonces

el castellano, llamado a la alta dignidad de lengua madre, habrá dejado en América, aun sin suspender el curso de su gloriosa carrera, cuatro idiomas, por lo menos, con un carácter de semejanza general, análogo al que hoy conservan los idiomas derivados del latín (p. 6).

Sus actitudes hacia las variedades hispanoamericanas diferían diametralmente de la que mantenía otro filólogo, Andrés Bello, durante la primera mitad del mismo siglo. El venezolano veía en las variedades hispanoamericanas productos espurios, formas bastardas que debían ser erradicadas a todo trance del suelo americano. Era la responsabilidad del gramático, como custodio de 
la pureza de una norma panhispánica, emplear todos los medios a su alcance para detener este proceso de creciente deterioro que amenazaba con destruir aquella única norma válida. Esta norma, basada en el uso de las personas instruidas de todo el mundo de habla española, era para el sabio venezolano el más importante vínculo de solidaridad entre las naciones del continente. Porque para Bello esta función unificadora que cumplía la norma panhispánica era de capital importancia, él temía que los cambios no sancionados por los gramáticos, la introducción de elementos nuevos, acarrearían en último término la destrucción de dicha norma, por eso advertía

...el mayor mal de todos, y el que, si no se ataja, va a privarnos de las inapreeiables ventajas de un lenguaje común, es la avenida de neologismos de construcción, que inunda y enturbia mucha parte de lo que se escribe en América, y alterando la estructura del idioma, tiende a convertirlo en una multitud de dialectos irregulares, licenciosos, bárbaros, embriones de idiomas futuros, que durante una larga elaboración reproducirán en América lo que fue la Europa en el tenebroso periodo de la corrupción del latín ${ }^{3}$.

Así pues, mientras a Bello le inquietaban los cambios, por cuanto atentaban contra este importantísimo carácter unificador de la lengua culta, y creía que la intervención del gramático podía estabilizar esa norma, para De Armas este carácter unificador no parecía tener importancia o era quizá un sacrificio que era necesario hacer en aras del progreso.

Evidentemente, las ciencias del lenguaje habían experimentado importantes progresos desde la época en que Bello escribió su Gramática hasta los días en que De Armas preparaba los Orígenes.

Hacia mediados de los setenta la gramática histórica, que en tiempos de Bello todavía no había trascendido los límites de su cuna germánica, se había extendido ya por el resto de Europa. Es posible que las ideas de los historicistas europeos, presentes ya en obras a las que tuvo acceso De Armas, hayan influido en su pensamiento. Entre estas obras podemos citar las de Antonio Bachiller, a cuya Cuba primitiva se refirió alguna vez nuestro autor.

Aunque en ninguna parte se refirió a Cuervo, es muy probable que mientras escribía los Orígenes hubiera leído las Apuntaciones del colombiano, y que esta obra hubiera tenido alguna

${ }^{3}$ ANDrés Bello, Gramática de la lengua castellana destinada al uso de los americanos, t. 4 de Obras completas, Pedro G. Ramírez, Santiago de Chile, 1883, p. 9. 
influencia sobre su pensamiento. Otra obra que seguramente debió de consultar con frecuencia, pero que tampoco citó, fue el Diccionario provincial, casi razonado, de voces y frases cubanas (1862) de Esteban Pichardo, obra que gozó de gran difusión en Cuba durante la mayor parte del siglo xix.

El propósito central del libro de De Armas, sin embargo, no era hacer una descripción de las zonas dialectales hispanoamericanas, sino tratar de desvirtuar una tesis según la cual las lenguas autóctonas antillanas, el llamado idioma lucayo, habían tenido una gran influencia en el desarrollo de la norma antillana, o lenguaje criollo, como él la llamaba. Aunque, como acabamos de indicar, De Armas no citó a Pichardo, nos inclinamos a creer que hacía referencia a la obra de éste cuando hablaba de "la infundada creencia... respecto a la conservación de millares de palabras del supuesto idioma lucayo'" (p. 12). En efecto, Pichardo caracterizaba como "voz de procedencia indígena" la mayoría de aquéllas cuyo origen antillano De Armas trataba de desvirtuar.

Nuestro autor partía de la premisa de que para que las lenguas aborígenes pudieran tener alguna influencia sobre el español debía existir una raza india fuerte, con una civilización avanzada y poseedora de una lengua altamente desarrollada. A través de frecuentes contactos, durante un lapso de tiempo prolongado, la lengua de esta raza podría llegar a influir sobre la de los conquistadores. Tal situación, en su opinión no se dio ni en Cuba, ni en las otras islas del Caribe.

Argüía que jamás existió en las islas un idioma lucayo único, sino multitud de lenguas, y respaldaba dicho aserto con el testimonio de cronistas como Las Casas y Fernández de Oviedo. Le parecía que

...no puede admitirse que las tribus antillanas, mucho más atrasadas, sin comunicación unas con otras, sin religión ni creencias, sin poblaciones, sin ninguna especie de vestidos, sin organización social, sin agricultura, sin designaciones nacionales ni geográficas, sin nombres propios siquiera, hasta sin instrumentos cortantes... contasen con un medio general y único de expresión en islas desparramadas por el Océano (p. 7).

La postura ecuánime de hombre de ciencia que De Armas adoptaba al hablar de su lenguaje criollo desaparecía por completo cuando se refería a las lenguas indígenas de las islas. Entonces 
el etnocentrismo y los prejuicios lingüísticos del ciudadano co* mún que se identificaba con una norma culta se ponían de manifiesto en la caracterización que hacía de estas lenguas:

Las lenguas antillanas eran necesariamente pobres de vocablos. Su construcción gramatical debió ser imperfecta, su articulación difícil y poco armoniosa. . . la lengua de Santo Domingo, la más importante para el filólogo moderno, padecía una gran penuria de vocablos y carecía de medios para contar objetos hasta más allá del número veinte. Hasta parece que sus posesores tenían alguna especie de imperfección orgánica, que en ciertos casos les impedía pronunciar bien dos vocales seguidas (pp. 9-10).

$\mathrm{Ni}$ las poblaciones de las islas ni sus lenguas ostentaban, pues, ninguno de los rasgos que según la tesis de De Armas posibilitarían alguna influencia sobre la variedad del español que se iba a desarrollar más tarde en la región. Apuntaba además que tanto las tribus antillanas como sus lenguas se extinguieron pocos años después de la conquista sin dejar rastros.

¿De dónde provienen, pues, las miles de palabras que se citan como pertenecientes a ese supuesto idioma lucayo? se preguntaba el investigador. Supuso que muchas de esas palabras eran corrupciones de formas españolas, nombres, a veces peregrinos, con que los exploradores peninsulares, muchos de ellos con un deficiente conocimiento del español, habían bautizado los objetos del Nuevo Mundo, asociando la nueva realidad con la ya conocida. Tampoco faltaron palabras vascuences con que los exploradores de esa nacionalidad dejaron memoria de su tierra. Además, como muchos de estos exploradores habían participado en las guerras de Granada y allí habían tenido contacto con el árabe, en tanto que otros eran moros o judíos conversos, no pocas de las supuestas palabras lucayas se derivaban de dicha lengua. Y tampoco faltaron los latinismos con que algunos exploradores dejaron testimonio de su formación clásica.

A juzgar por el acopio de citas que encontramos en su libro, De Armas conocía muy bien la obra de los cronistas, especialmente del Padre Las Casas, de Pedro Mártir y de Fernández de Oviedo. También estaba familiarizado con el Diálogo de la lengua de Juan de Valdés, la Gramática de la lengua castellana de Nebrija y la obra de Francisco de las Casas y del Marqués de Villena. A través de estas lecturas se había formado una idea razonablemente aproximada de las características fonológicas del español 
que llegó a América en la época del descubrimiento y la conquista, pero en su afán por negar el origen antillano a los vocablos en discusión, frecuentemente ignoró el testimonio fonológico.

Echando, pues, a volar su fértil imaginación, se dio a la tarea de dilucidar las etimologías de los para él supuestos antillanismos y llegó a resultados que muchas veces sorprenden por lo descabellado.

Así, por ejemplo, define aji como una "planta espinosa de África, que echa flores purpúreas y una frutilla roja" (p. 45), cuyo nombre derivaba del árabe haxixa o haaxi. De origen árabe se le antojan también barbacoa de barbac, sumidero; cacique, sinónimo de jeque en el reino alarbe de Mazagán, y cazabe, "del verbo [árabe] casabe, que vale lo mismo que guarnecerse y fortalecerse" (p. 50). Cree que tienen etimología española aura, "un ave inmunda que al aura se posa sobre los árboles"' (p. 26); canoa, de la raíz cana, que se encuentra en canal, canuto, canela; jagua, árbol que echa agua; y maiz, de fruto semejante al mahizo, o espiga acanalada con que terminaba el huso de las hilanderas. La iguana, por último, procede en su opinión de "Yuana, o sea Juana en ortografía moderna; lo que fue gran desacato, si en ese ser de apariencia horrible, y de majestad ridícula, quisieron recordar a la reina doña Juana, sobrenombrada la loca"' (p. 24).

Señalemos de paso que esta postura anti-indigenista de De Armas no era entonces un fenómeno aislado. Como lo observa López Morales (1971), José Miguel Macías adoptaba una postura aún más extrema en su Diccionario cubano, etimológico, crítico, razonado y comprensivo, donde llegaba a afirmar que "... lo que se habla [en toda América] es castellano, no son lenguas indígenas, sino cástellances; esto es, romances corrompidos" 4 .

Más modernamente, Santamaría, Diccionario general de americanismos (1942), se refiere a De Armas ya para refutar algunas de sus caprichosas etimologías, ya en apoyo de las propias ${ }^{5}$.

Vemos en las aseveraciones de De Armas y de Macías manifestaciones bastante militantes de la lealtad lingüística hacia un bien cultural valioso como es el idioma castellano, a través del cual estos intelectuales se ligan a la cultura europea occidental. $\mathrm{El}$ orgullo que experimentan por poseer esta lengua los lleva a

${ }^{4}$ Apud Humberto López Morales, Estudios sobre el español de Cuba, Las Américas, New York, 1971, p. 148.

${ }^{5}$ Cf. también Marcos A. Morínigo, Diccionario manual de americanismos, Muchnik Editores, Buenos Aires, 1966. 
tratar de desembarazarla de elementos bastardos como son desde su perspectiva los indigenismos y a postular que ellos provienen de ultramar o proceden de lenguas indígenas "superiores".

La norma antillana del español, según la concebía De Armas era el idioma que

empezó a formarse en las Antillas, sobre la ancha base del idioma castellano, desde los primeros días del descubrimiento, se propagó con la conquista al continente, siendo designado en sus principios con el nombre de lengua de las islas; se enriqueció a su vez con multitud de vocablos de las nuevas regiones conquistadas; adquirió homogeneidad y un carácter distintivo, con los primeros criollos; allegó a su formación los más variados componentes; y hoy constituye un cuasi dialecto castellano, que comprende el litoral del mar Caribe, y que será sin duda, para una época aún remota, la base de un idioma, hijo del que trajeron los descubridores y conquistadores de América (p. 5).

En opinión de nuestro autor, además del español, contribuyeron a darle su sabor propio a esta nueva norma el habla marinera, el vascuence, que contribuyó a enriquecer la toponimia, el árabe y las lenguas indígenas de México y del Perú.

En conclusión, quisiéramos repetir que, a pesar de los ahora inconcebibles errores en que cayó De Armas tratando de probar la ausencia de un sustrato taíno o lucayo en el español antillano, su obra lo sitúa entre los primeros estudiosos que con una actitud científica aportó una visión global bastante acertada de las áreas dialectales hispanoamericanas. Es necesario observar que su propuesta, a pesar de los escasos datos fidedignos con que contó al momento de formularla es, en algunos aspectos, de mayor validez que algunas de investigadores posteriores, como la citada clasificación de Henríquez Ureña, clasificaciones para las cuales éstos contaron con fuentes de información decididamente superiores.

AlFredo TorRejón Auburn University, Alabama. 